\section{THE VARLEY TESTIMONIAL.}

A $\mathrm{N}$ important Committee, containing among others, Lord Kelvin, Prof. Ayrton, Prof. G. Forbes, Dr. Gladstone, Prof. D. E. Hughes, Dr. J. Hopkinson, Prof. Kennedy, Prof. O. Lodge, Prof. J. Perry, Messrs. W. H. Preece, A. Siemens, A. Stroh, J. W. Swan, and Prof. S. Thompson, has been formed, to give effect to the feeling amongst some of the older members of the electrical profession that the life-long labours in electrical research of Mr. S. A. Varley should be recognised by some substantial testimonial befitting his reputation as a scientific investigator.

A brief sketch of Mr. Varley's career will serve to show what signal services he has rendered to the cause of electrical science and the honour his discoveries have conferred upon this country.

Mr. Samuel Alfred Varley was born in London in I832, and was the third son of the late Mr. Cornelius Varley, an active man of science and an artist. In 1858 , when the Atlantic cable was being constructed, he wrote a paper, read before the Institute of Civil Engineers, "On the Electrical Qualifications requisite in Long Submarine Cables," and was shortly afterwards elected an Associate Member of that Institution.

In the paper referred to above, Mr. Varley opposed the views of the electrical advisers of the company. Faraday, who had publicly supported their opinions, endorsed Mr. Varley's ideas immediately after receiving a copy of his paper. Mr. Varley followed this up by reading a second one before the Society of Arts in 1859 , "On the Practical Bearing of the Theory of Electricity to Long Submarine Telegraphy." In this paper he suggested, among other things, the use of artificial lines, which have since proved of such value in connection with duplex working. In I $866 \mathrm{Mr}$. Varley discovered for himself the re-action or self-exciting principle, and at that early date constructed his first machine of the pure dynamo type, which is now in the Museum at South Kensington. His dynamo of I 866 was exhibited at the Inventions Exhibition of I885, and for this he was awarded a gold medal.

The controversy which subsequently arose on this invention may be held to have been fitly summed up by the late Robert Sabine, C.E. (son-in-law of Sir Charles Wheatstone), in the following words :-_"Professor Wheatstone says he was the first to complete and try the reaction machine. Mr. S. A. Varley was the first to put the machine officially on record in a provisional specification, dated December 24, I866, which was, therefore, not published until July, I867. Dr. Werner Siemens was the first to call public attention to the machine in a paper read before the Berlin Academy on the I7th January, I 867." (See Engineering, November, 1877.)

In 1866 he introduced needle-telegraph coils, in which soft-iron magnetically-induced needles were substituted for tempered steel needles. These induced and consequently undemagnetisable needles entirely superseded the old form introduced by Wheatstone and Cooke, and were largely adopted by the Postal Department. In the same year (1866) he designed a system of electric train inter-communication.

In the year i875 Mr. Varley became assistantmanager of the works of the late British Telegraph Manufactory, Limited, and as the first Gramme machines constructed in England were manufactured by this firm, he had ample opportunities of studying the characteristics of both series wound machines and those having a seperate armature for excitation of the field magnets. There is scarcely a doubt that Mr. Varley's investigations at this period led to the invention of compound winding, for in I 876 he patented a series-shunt or compound-wound dynamo, and, in three legal suits, the claim that this specification first described a system of compound winding has been fully sustained. Mr. Varley has from time to time contributed papers read at the meetings of the British Association, among which may be mentioned one "On the Mode of Action of Lightning on Telegraph Circuits," wherein he described a lightning bridge designed by himself, a number of which are now doing duty, although fitted up more than twenty years ago.

But Mr. Varley's magnum opus is the important part which he took in the invention and perfecting of the dynamo, perhaps the most striking invention of the century, and upon this his fame as a patient, conscientious, and earnest scientific investigator of the Faraday school will permanently rest. His researches were undertaken in the true spirit of science, and no thought of self-emolument has ever caused him to deviate from the path which he has pursued throughout an eventful, although eminently simple and blameless life, a life in which selfdenial and self-sacrifice have had no small share. Like many men of genius he was far ahead of the times, and has lived to see others reap the benefit of his great discoveries. His nervous and retiring disposition has for years kept him from the busy haunts of men, and to the younger generation of electricians he exists only in name, a name, however, that will live as long as the dynamo is employed in the service of man.

Subscriptions will be gladly received by the hon. treasurer, Mr. Stroh, 8 Haverstock Hill.

\section{NOTES.}

THE Electrician for A ugust 5 contains an article on Lord Rayleigh, which is accompanied by a steel portrait.

AT a recent meeting of the Berlin Geographical Society, the chairman, Baron von Richthofen, announced that the society was about to publish, in com memoration of the 400 th anniversary of the discovery of America, a work descriptive of the ancient manuscripts and maps in the Italian libraries relating to the history of this event. The German Emperor has promised a contribution of 15,000 marks towards the expense of the under. taking, and it is to be edited by Dr. Kretschmer. The accompanying atlas will contain thirty-five large maps, of which thirty-one are new, and will be published for the first time.

At the lunch in the Library Hall, St. Andrews, on the IIth, to the party from the British Association, Prof. McIntosh announced that Mr. Charles Henry Gatty, of East Grinstead, had presented $£ \mathbf{r}, 000$ for the purpose of establishing a Marine Laboratory at St. Andrews, which sum he further increased to $£ 2,000$ before the close of the day. The name of Mr. Gatty is sufficiently familiar to marine zoologists, were it only in connection with the accomplished lady (Mrs. Alfred Gatty), the favou. rite correspondent of Dr. George Johnston, of Berwick-onTweed. Mr. Gatty's munificent donation will enable St. Andrews to have a substantial and comfortable laboratory instead of the wooden building (formerly a fever hospital), which has hitherto been used for marine work since the period of the Trawling Commission under Lord Dalhousie. St. Andrews Marine Laboratory is the oldest permanent station in the country, and, as it has pre-eminent advantages in regard to varied and very rich marine fauna and flora, easy access to a fine University Library, and a University Museum--unique in certain departments, a new future is opened to it through $\mathrm{Mr}$. Gatty's handsome gift. At the same meeting it was stated that the Fisheries prize of $£ 20$ given annually to the best student of Zoology (hitherto from an anonymous donor) was the gift of Mr. J. W. Woodall, of Scarborough. Both Mr. Gatty and Mr. Woodall were present.

DURING the past week the weather has been fine generally over the southern portion of the kingdom, but somewhat unsettled. The anticyclonic conditions which prevailed for a day or two NO. I I 90 , vOL. 46] 